http://journal.uinsgd.ac.id/index.php/biodjati

\title{
ANATOMICAL STRUCTURE OF SEPAL AND PETAL OF RED DRAGON FRUIT (Hylocereus polyrhizus Britton \& Rose) DURING FLOWER DEVELOPMENT
}

\author{
Utaminingsih $^{* 1}$, Sulhan Etfanti ${ }^{2}$, Suharyanto ${ }^{3}$, Maryani ${ }^{4}$
}

Received : April 30, 2019

Accepted : September 11, 2019

DOI: 10.15575/biodjati.v4i2.4581

1,2,3,4 Laboratory of Plant Structure and

Development, Faculty of Biology, Universitas Gadjah Mada

J1. Teknika Selatan, Senolowo, Sinduadi, Mlati, Sleman, Daerah Istimewa Yogyakarta 55281, Indonesia telp. (0274) 580839

e-mail:

*1utaminingsih@ugm.ac.id 2sulhan.etfanti@gmail.com

3haryantobiougm@ugm.ac.id

4mmyani@ugm.ac.id

*Corresponding author
Abstract. Red dragon fruit (Hylocereus polyrhizus Britton \& Rose) is one type of cactus plant which is very potential as an ornamental plant and edible fruit. Flower is organ that play an important role in the process of breeding plants generatively. This reasearch aimed to study the anatomical structure of sepals and petals of red dragon fruit plants during flower development. The research stages included: sepals and petals sampling that held at various stages of flowering ; morphological observation (measurement length of sepals and petals); anatomical slides of sepals and petals cross section using the embedding method, anatomical observation and image capture of sepals and petals. The parameters observed were bud size, sepal length, petal length, sepal thickness, petal thickness, and tissue description composed. The results of this study indicated that buds have an increased development pattern. The increase in bud size is directly proportional to the stage of the bud. Sepal and petal are composed of epidermal tissue which form papillae, cryptophore stomata, secretory parenchyma space containing mucus, and tissues transport system is closed collateral.

Keywords: flower development, Hylocereus polyrhizus, paraffin method, petal, sepal

\section{Citation}

Utaminingsih, Etfanti, S., Suharyanto \& Maryani. (2019). Anatomical Structure of Sepal and Petal of Red Dragon Fruit (Hylocereus polyrhizus Britton \& Rose) During Flower Development. Jurnal Biodjati, 4(2), 163-174

\section{INTRODUCTION}

Dragon fruit are cactus plants originating from South America which then expanded to Australia, China, Israel, Malaysia, Nicaragua, Taiwan, Vietnam and Indonesia. This plant could live up to 20 years in a life cycle; accommodate \pm 800 plants for a hectare crop and could produce fruit after two years planting and reach maximum production in the 5 th year (Gunasena et al., 2006).

Dragon fruit are a perennial and fastgrowth plant, scandens with 3-5 angled stems.
Fleshy stem has several branching segments. Each segment has three wavy or bony wings with 1-3 spines. The stem height can reach 6 $\mathrm{m}$ or more depends on environmental factors (Gunasena et al., 2006).

Red dragon fruit is included in tropical fruit, with production of 2,645,111 tons in Indonesia in 2016 (Faostat, 2018). With good seed selection, planting and care, the average production of dragon fruit per week could reach $768 \mathrm{~kg} / 1,000$ populations in the first year, for the second and third years at 1,800 $\mathrm{kg}$ and 4,300 $\mathrm{kg}$ with a average weight of 400 - 


\section{JURNAL BIDDJATI}

http://journal.uinsgd.ac.id/index.php/biodjati

$500 \mathrm{~g}$ (Jatnika, 2010).

Flower is the reproductive organ of the angiosperm and become the main organ that distinguishes from other plants. Morphologically complete flowers are composed of sepals, petals, gynoecium and androecium. Sepal is an organ covers all parts of flower buds. Petal is the flower organ with some various colors. Gynoecium is a female reproductive organ, while androecium is a male reproductive organ (Dickison, 2000).

Dragon fruit's flowers grow at the sides of the stem; each stem consists of 3-5 flowers. The flowers are large with maximum length of $28 \mathrm{~cm}$, bells-like shaped, hermaphrodite, very striking smell and open only at night. Temperature and light intensity also affect the flowering process. In cold temperatures, anthesis can be delayed for up to 8 hours. If the pollination does not occur, the flowers will remain open until morning. Development of flowers from bud to complete opening takes 25-35 days (Weiss et al., 1994).

In angiosperm, sepal is generally green, while petal is an attractive organs for pollinating insects (Nugroho et al. 2012). Sepal and petal have anatomical shapes and structures similar to leaves. The cross section of anatomical structure of the sepals and petals is composed of the abaxial and adaxial epidermis, the transport tissues and the mesophyll tissues. In mesophyll, there are idioblast cells containing crystals. Trichome and stomata can be found in the epidermis. Chromoplasts contain carotenoids are found in petals. Various petals color is influenced by secondary metabolite called anthocyanin. It is a kind of flavonoid compound found in the vacuole of petal cells (Hidayat, 1995).

Research on the development anatomy of red dragon fruit flowers has not been studied so far. Therefore, this research aimed to study the anatomical structure of sepals and petals of red dragon fruit plants during flower development.

\section{MATERIALS AND METHODS}

\section{Materials}

The tools used in this study including oven, rotatory microtome (Shibuya Optical Co., Ltd.) No. 525, Microscope Nikon BM108, optilab camera Miconos Upgrade Edition, glassware and hotplate. The materials used for anatomical preparation were sepal and petal of red dragon fruit flowers at various stages of development, glacial acetic acid, alcohol, xylol, glycerin, albumin, safranin, canadian balm and paraffin.

\section{Methods}

The research stages include: sampling, which held at various stages of flowering; morphological observation (measurement length of sepals and petals); sample preparations using the embedding method (Johansen, 1940) with modifications, as well as anatomical observation and image capture of sepals and petals. The flowers of the red dragon fruit were taken from plants grown in the Bona Mitra Multifarm Dragon Fruit Garden, Jln. Jengger Lempongsari, Ngaglik, Sleman, Yogyakarta. The 5 replications was used at each stage of flower development . The sepals and petals used for anatomical observation were taken from the outer layer. Sepal and petal were taken at various stages of flower development (Table 1.). Determination of the age of interest was based on preliminary observations. The development of dragon fruit plant flowers from buds to blooms was for \pm 20 days.

Sepal and petal were soaked for 24 hours in FAA solution (Formalin : Glacial Acetic Acid : Alcohol 70\% = $5: 5$ : 90). Fixation solutions were discarded then replaced 


\section{JURNAL BIDDJATI}

http://journal.uinsgd.ac.id/index.php/biodjati

successively with Alcohol 70\%, 80\%, 95\%, $100 \%$ twice, for 30 minutes each, then dealcoholization with a mixture of alcohol / xilol 3 : 1, alcohol / xilol 1: 1, alcohol / xylol 1:3, xilol 2 times for 30 minutes each, then continued with a mixture of xilol / paraffin $1: 9$ with a temperature of $57^{\circ} \mathrm{C}$ for 24 hours. Xylol / paraffin mixture was removed and replaced with pure paraffin, then left for 24 hours at $57^{\circ} \mathrm{C}$. Paraffin was removed and replaced with new pure paraffin, then the blocking was made after 1 hour. The block was made transversely by using Rotary mycrotome with a variation of thickness of $16 \mu \mathrm{m}$. The slices were glued to a glass of objects with glycerin albumin, and placed on a hot plate with a temperature of $45^{\circ} \mathrm{C}$ until the paraffin tape stretches. Coloration using 1\% safranin in Alcohol 70\%.
Glass objects were inserted in: xylol 2 times, alcohol / xilol $1: 3$, alcohol / xilol $1: 1$, alcohol / xilol $3: 1$, alcohol 100\% twice 95\%, $80 \%, 70 \%$ with each for 3 minutes, then safranine $1 \%$ in alcohol $70 \%$ for 1 hour. alcohol $70 \%, 80 \%, 95 \%, 100 \%$ twice, alcohol / xylol 3: 1, alcohol / xilol 1: 1, alcohol / xilol $1: 3$, xilol 2 times each 1 minute. The slices were then covered with a cover glass that was previously dripped with Canadian Balsam first. Then the preparat were dried on the Hot Plate with a temperature of $45 \%$ by dry Canadian balsam. The parameters observed were bud size, sepal length, petal length, sepal thickness, petal thickness, and description of compesed of sepal and petal.

Table 1. Stages of the flower buds development of red dragon fruit plants

\begin{tabular}{cll}
\hline Stage Days before anthesis & \multicolumn{1}{c}{ Characteristics } \\
\hline 1 & \pm 17 & $\begin{array}{l}\text { The size of the flower is } \pm 1 \mathrm{~cm} \text {, green color of petal with red tinge on the } \\
\text { edges and end } \\
\text { The size of the flower is } \pm 5 \mathrm{~cm} \text {, green color of petal with red on the edges } \\
\text { and the middle end } \\
\text { The size of the flower is } \pm 11 \mathrm{~cm} \text {, the petals are green with red on the edges } \\
\text { and the middle end } \\
\text { The size of the flower is } \pm 21 \mathrm{~cm}, \text { buds look elongated so that they can be } \\
\text { distinguished from the hypanthium section } \\
\text { The size of the flower is } \pm 30 \mathrm{~cm}, \text { the bud has reached its maximum size, the } \\
\text { flower buds are lighter in color with red on the edges of the petals }\end{array}$ \\
\hline 5
\end{tabular}

\section{Data Analysis}

Quantitative data were in the form of bud length, sepal length, and petal length, while qualitative data included a description of tissue composed of sepal and petal at various stages of flower development. Quantitative data on measurement results were analyzed by ANOVA. To find out the real difference between treatments, further testing was carried out with DMRT (Duncan Multiple Range Test) with a confidence level of $95 \%$. Jurnal Biodjati 4(2):163-174, November 2019

\section{RESULTS AND DISCUSSION}

\section{Flower Bud Development}

The flower bud of red dragon fruit is conical-shaped. It enlarges and increases in length, especially in the middle part area. The buds are green with purplish red on the edges of the sepals and protective leaves. The bud length (Table 2.) increases with age. In stages 1 to stage 3, buds increased in size by $33 \%$, while stage 3 to stage 5 it increased by $67 \%$. 
Jurnal Biodjati 4(2):163-174, November 2019

\section{JURNAL BIDDJATI}

http://journal.uinsgd.ac.id/index.php/biodjati

The size of the bud length increases with increasing of the bud stages. The percentage of increase in bud length from stage 1 to stage 3 was lower than from stage 3 to 5 .

Table 2. The morphology and length of the sepals of red dragon fruit flowers at various stages of development.

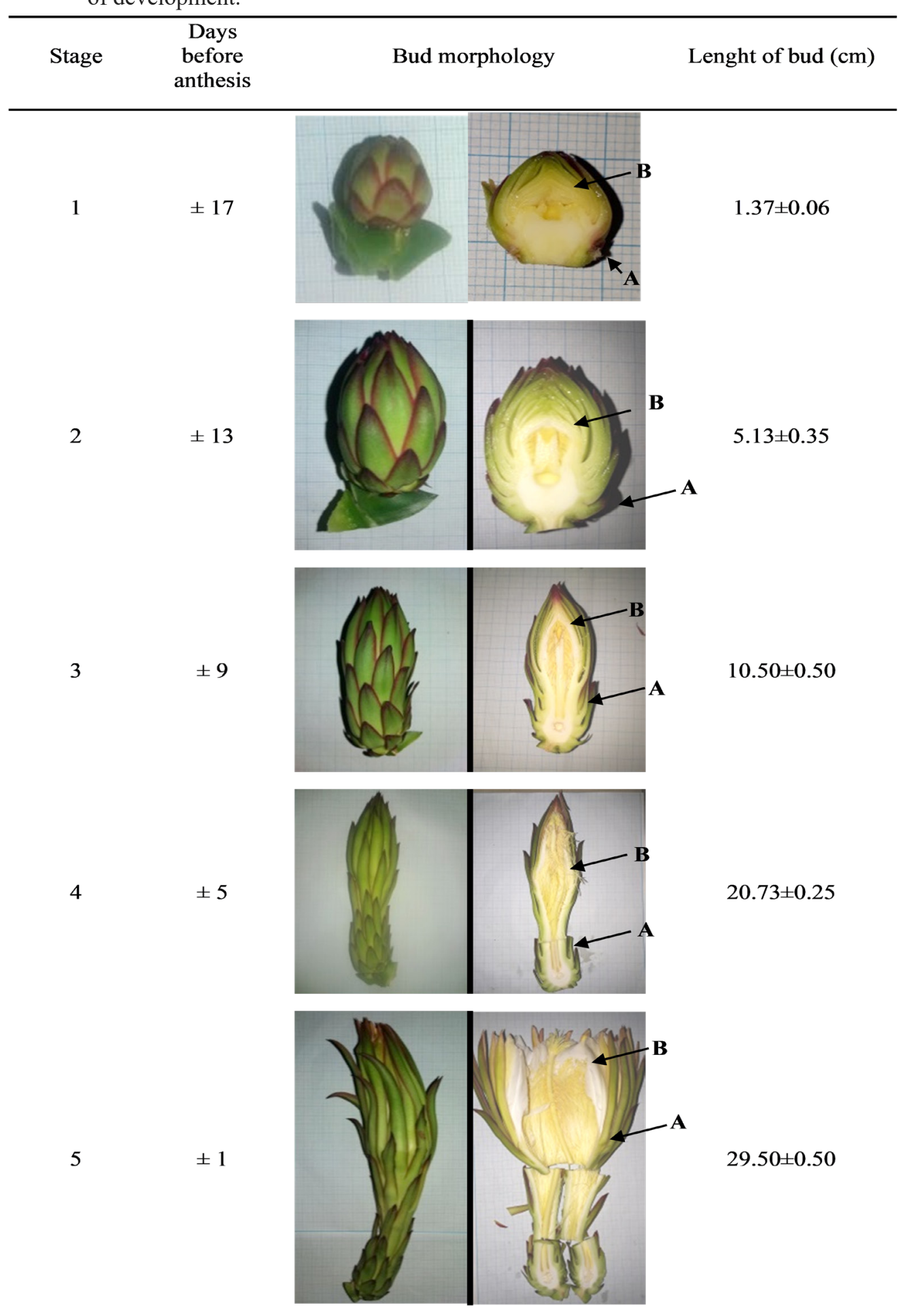

Information : A. Sepal, B. Petal 


\section{JURNAL BIDDJATI}

http://journal.uinsgd.ac.id/index.php/biodjati

Flower buds usually grow or appear in the axill. The development of flowers begins with the appearance of small bud which grows larger and more mature as time increase followed by anthesis and fertilization process. Flower buds are composed of sepals, petals, filaments, anther, stigma, stylus, and ovaries. During bud development there will be a swelling caused by the development of the ovary, anther and stigma (Deswiniyanti et al. 2015).

The number and size of bud cells increases as well as differentiates to form tissues and organs with certain functions. Srivastava (2002) stated that in the plants, the developmental process is composed of the growth, differentiation, and morphogenesis. Growth is defined as an increase in mass due to the addition of cell numbers and cell elongation. Differentiation means qualitative changes that occur in cells that cause differences with ancestor cells. Morphogenesis is the acquisition of special shapes in plants.

\section{Sepals Development}

Sepal is one of the flower accessories that serve to protect the young flower. The results of the measurement of sepal length are presented in Table 3. The length of the sepals increased in concomitant with the age of the flower (Figure 1). In stages 1 to stage 2 the length of the sepals increased by $2.6 \mathrm{~cm}$ (21.61\%), stages 2 to 3 increased by $2.8 \mathrm{~cm}$ (23.71\%), stages 3 to stage 4 increased 2.4 $\mathrm{cm}(20.08 \%)$, and stages 4 to 5 increased 4.1 $\mathrm{cm}(34.58 \%)$. In stage 5 the sepal length has reached its maximum size.

The development of sepals has the same pattern as bud development. It proves that flower bud development is influenced by the development of sepals. The longer the sepal, the bigger the size of the flower bud. Anatomically, the sepal is composed of epidermis and mesophyll. The epidermal derivatives are papillae and stomata. Mesophyll is composed of the hypodermic layer, secretion space, transport tissues and parenchymal tissue (Figure 2).

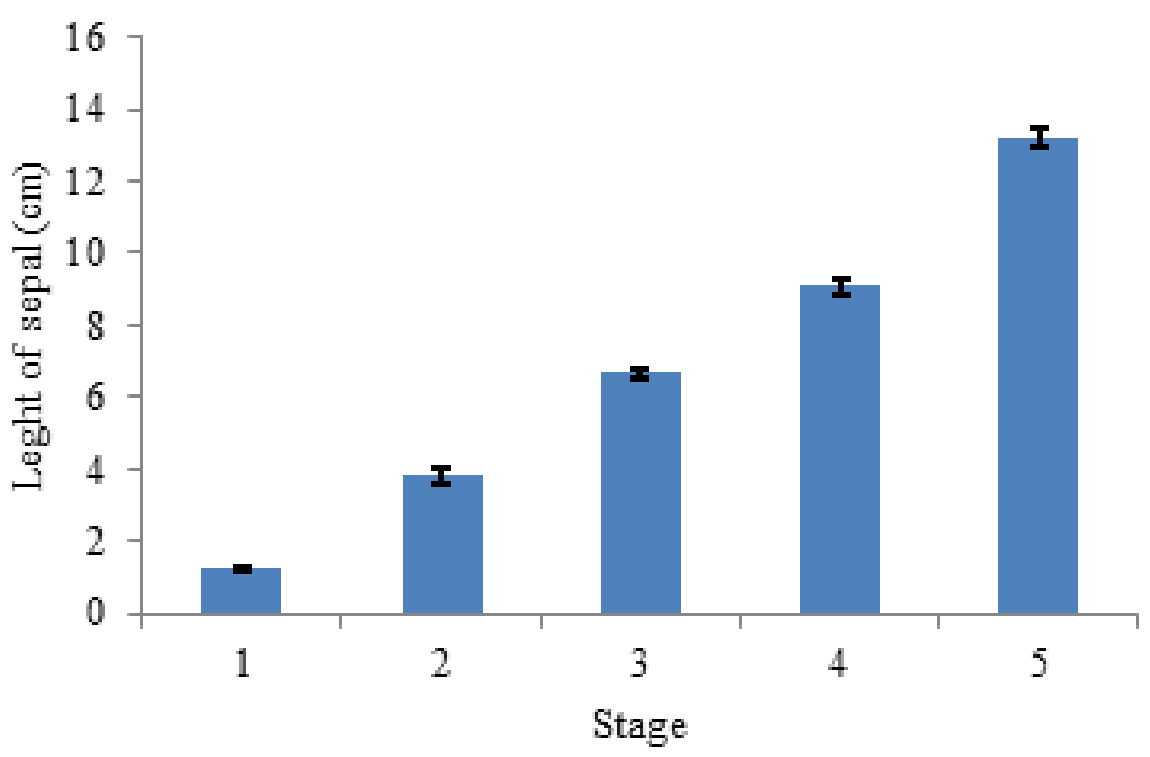

Figure 1.Lenght of sepal at various stage of flower development 
Jurnal Biodjati 4(2):163-174, November 2019

\section{JURNAL BIDDJATI}

http://journal.uinsgd.ac.id/index.php/biodjati

Table 3. The morphology of sepal of red dragon fruit flowers at various stages of development

\begin{tabular}{|c|c|c|c|c|c|c|}
\hline Stage & $\begin{array}{c}\text { Days before } \\
\text { anthesis }\end{array}$ & $\begin{array}{c}\text { Morphology of } \\
\text { sepal }\end{array}$ & $\begin{array}{l}\text { Lenght of } \\
\text { Sepal (cm) }\end{array}$ & $\begin{array}{l}\text { Sepal } \\
\text { shape }\end{array}$ & Tip shape & Base shape \\
\hline 1 & \pm 17 & & $1.25 \pm 0.05$ & Round & Rounded & Rounded \\
\hline 2 & \pm 13 & & $3.83 \pm 0.23$ & Oval & Tapered & Rounded \\
\hline 3 & \pm 9 & & $6.67 \pm 0.15$ & Oval & Pointed & Rounded \\
\hline 4 & \pm 5 & & $9.07 \pm 0.25$ & Lancet & Pointed & Even \\
\hline 5 & \pm 1 & & $13.20 \pm 0.26$ & Lancet & Pointed & Even \\
\hline
\end{tabular}

In stage 1 sepals have lamellar adaxial epidermis, oval shaped of abaxial epidermis, panerophore stomata, and no space between cells. Mesophylls are composed of colenchymal tissue, parenchymal tissue, transport tissues in the middle, and secretory cells that are spreaded between parenchymal cells (Fig- ure 2. A). In stage 2, flat adaxial epidermal cells does not swell; panerophore stomata; inter-cell space exists ; colenchymal tissue and secretion space (Figures 2. B, F \& H).

In the $3^{\text {rd }}$ stage, buds are with length of $10.50 \pm 0.50 \mathrm{~cm}$, flat adaxial epidermal cells can be observed; panerophore stomata with 


\section{JURNAL BIDDJATI}

http://journal.uinsgd.ac.id/index.php/biodjati

guard cells begin to sink; intercellular space is greater; thicker wall of colenchymal tissue (Figure 2. $\mathrm{C} \& \mathrm{G}$ ). In the $4^{\text {th }}$ stage, buds are found with length of $20.73 \pm 0.25 \mathrm{~cm}$, flat and dense adaxial epidermal cells; papillae are found in the abaxial epidermis; cryptophore stomata; thick colenchymal tissue, and large secretion space (Figure 2. D \& I).

In the $5^{\text {th }}$ stage, buds with length of 29.50 $\pm 0.50 \mathrm{~cm}$, adaxial epidermal cells is flat and dense; papillae found in the abaxial epidermis; stomata type is cryptophore; thick colenchymal tissue; intact and large vascular bundle; large secretion space (Figure 2. E \& H).

Based on the observations of sepal cross section, it is known that anatomical develop- ment of sepals reached its maximal length in the $5^{\text {th }}$ stage. The flower sepals are composed of abaxial and adaxial epidermis. Stomata are located in the abaxial and adaxial epidermis. Papilla is present in the abaxial epidermis. Cryptophore stomata, the type of vascular bundle is closed colateral and the secretion space is arranged scattered. Mesophyll is composed of parenchymal tissue.

Papillae in sepals is one of epidermal derivatives which produces secrets. Papillae are found in various floral organs (Fahn, 1991). According to (Nugroho et al., 2012), papillae are found on the surface of petal flowers. In red dragon fruit, the papilla is only found in the sepal abaxial epidermis.

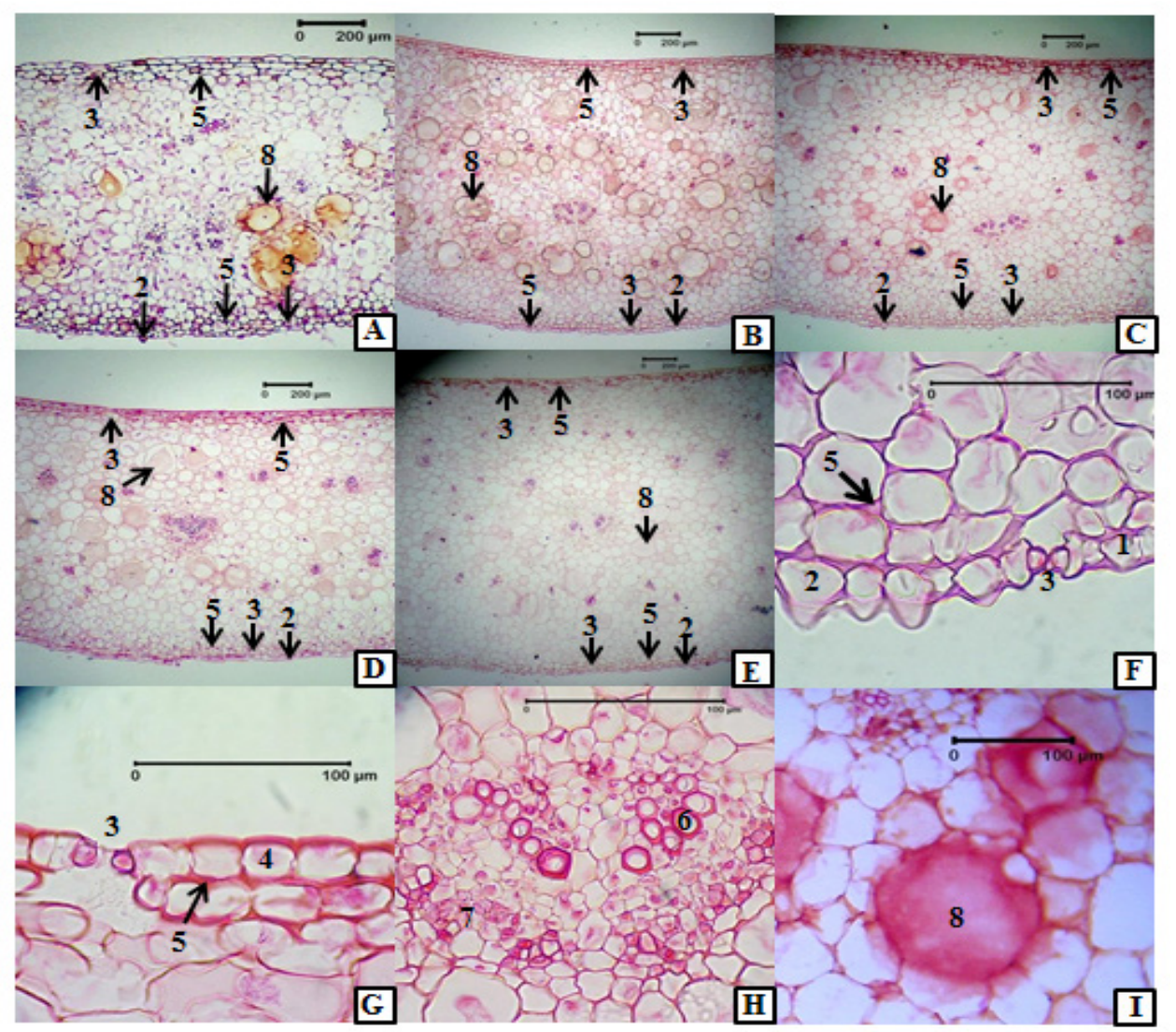

Figure 2. Cross section of the sepal of a red dragon fruit plant at various stages of development. $\mathrm{A}=$ stage $1 ; \mathrm{B}=$ stage $2 ; \mathrm{C}=$ stage $3 ; \mathrm{D}=$ stage $4 ; \mathrm{E}=$ stage $5 ; \mathrm{F}=$ part of the abaxial epidermis; $\mathrm{G}=$ adaxial epidermis; $\mathrm{H}=$ vascular bundles; $\mathrm{I}=$ secretory space. 1) abaxial epidermal cells, 2) papillae, 3) stomata, 4) adaxial epidermis, 5) colenchymal tissue, 6) xylem, 7) phloem, 8) secretory space. 


\section{JURNAL BIDDJATI}

http://journal.uinsgd.ac.id/index.php/biodjati

\section{Petals Development}

The petal is the colored part of the flower and plays an important role to attract insect pollinator. The petal structure resembles a leaf and has a simple structure. The anatomical structure of both leaves and petals have parenchyma tissue with vascular bundle (Table 4 and Figure 3).

Table 4. The morphology of petal of red dragon fruit flowers at various stages of development

\begin{tabular}{|c|c|c|c|c|c|c|}
\hline Stage & $\begin{array}{c}\text { Days } \\
\text { before } \\
\text { anthesis }\end{array}$ & $\begin{array}{c}\text { Morphology } \\
\text { of Petal }\end{array}$ & $\begin{array}{l}\text { Lenght of } \\
\text { Petal }(\mathrm{cm})\end{array}$ & Petal shape & Tip shape & Base shape \\
\hline 1 & \pm 17 & & $0.2 \pm 0.00$ & Round & Rounded & Rounded \\
\hline 2 & \pm 13 & $\Rightarrow$ & $1.2 \pm 0.24$ & Round & Rounded & Rounded \\
\hline 3 & \pm 9 & & $3.2 \pm 0.35$ & Oval & Rounded & Rounded \\
\hline 4 & \pm 5 & & $6.6 \pm 0.32$ & Oval & Pointed & Tapered \\
\hline 5 & \pm 1 & & $10.8 \pm 0.4$ & Oval & Pointed & Pointed \\
\hline
\end{tabular}

The increases of petal length from stages 1 to stage 4 were $9.56 \%, 18.33 \%, 32.60 \%$, and $39.49 \%$. In stage 5 the petal length reached its maximum size. Petal length increases in concomitant with increasing petal stages. The pattern of development of the petal is similar to the pattern of flower bud development, which increases with age (Figure 5).

Utaminingsih et al.
Flower petals of red dragon fruit plants are composed of the adaxial epidermis, abaxial epidermis, and mesophyll. In the epidermis there are cuticles and stomata. The mesophyll section is composed of the hypodermic layer, secretion space, vascular bundle and parenchymal tissue (Figure 4). 
Jurnal Biodjati 4(2):163-174, November 2019

\section{JURNAL BIDDJATI}

http://journal.uinsgd.ac.id/index.php/biodjati

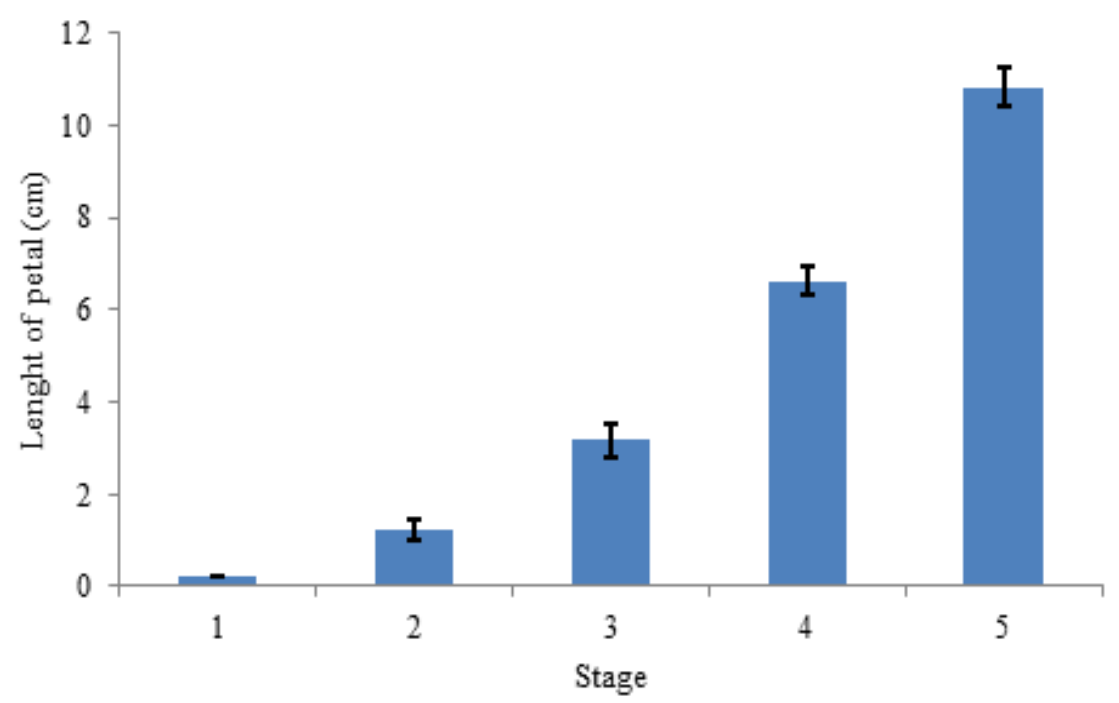

Figure 3. Lenght of sepal at various stage of flower development

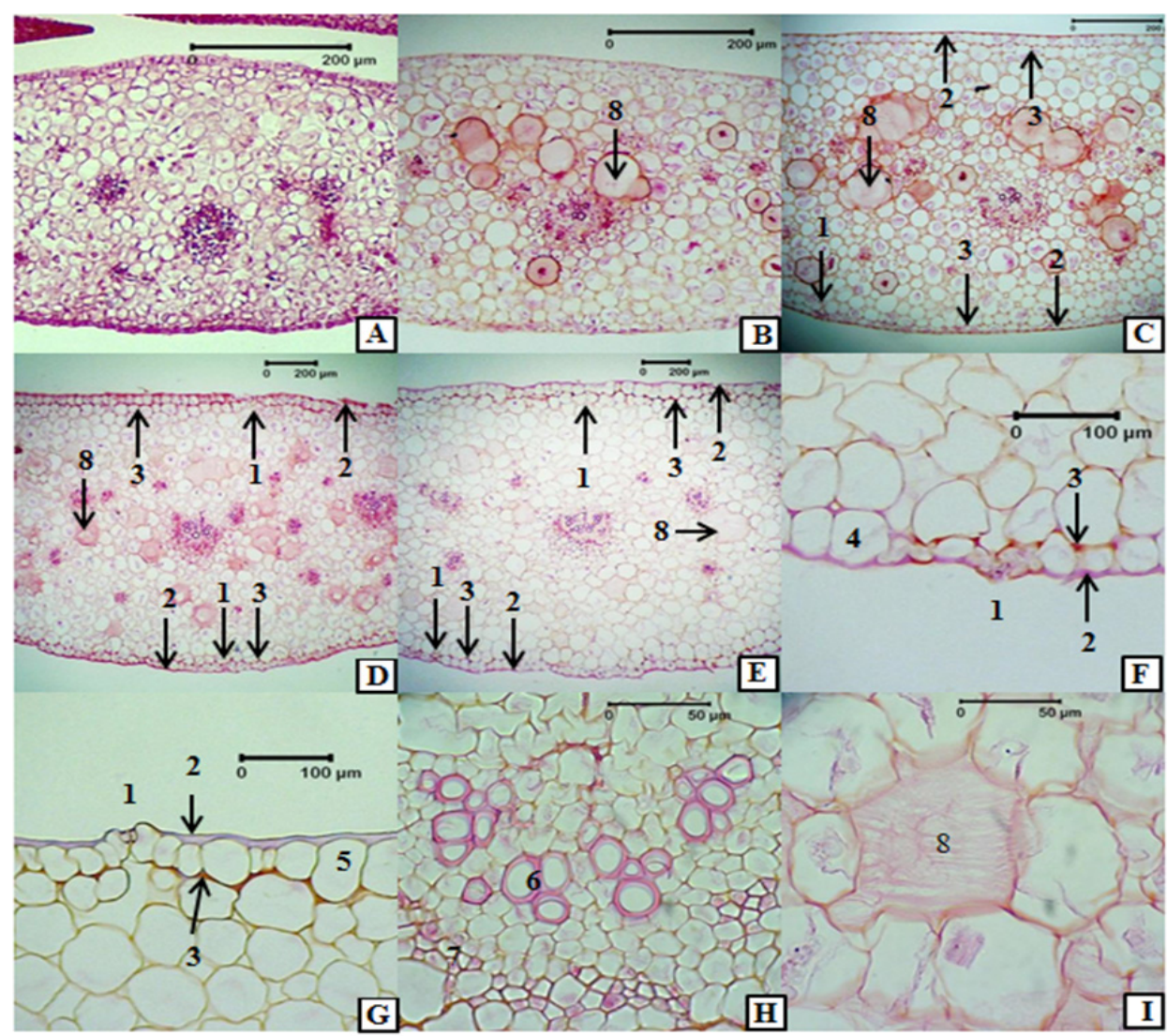

Figure 4. Cross section of the petal of a red dragon fruit plant at various stages. $\mathrm{A}=$ stage $1 ; \mathrm{B}=$ stage $2 ; \mathrm{C}=$ stage $3 ; \mathrm{D}=$ stage $4 ; \mathrm{E}=$ stage $5 ; \mathrm{F}=$ the part of the abaxial epidermis; $\mathrm{G}=$ the part of the adaxial epidermis; $\mathrm{H}=$ vascular bundles; $\mathrm{I}=$ secretory space. 1) stomata, 2) cuticles, 3) colenchymal tissue 4) abaxial epidermis, 5) adaxial epidermis, 6) xylem, 7) phloem, 8) secretory space. 


\section{JURNAL BIDDJATI}

http://journal.uinsgd.ac.id/index.php/biodjati

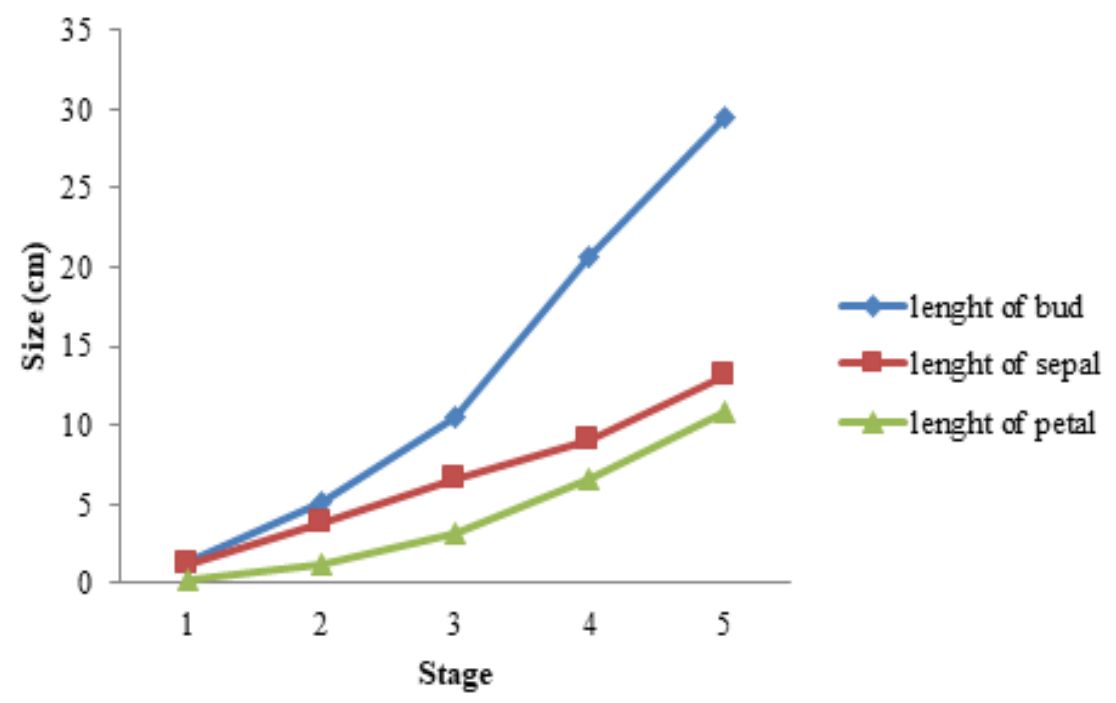

Figure 5. Lenght of bud, lenght of sepal, and lenght of petal at various stage of flower development

In stage 1, the epidermal cuticle was not observed. The petal epidermis is composed of a single rectangular cell layer, no stomata was observed. Epidermis has small cells with no intercellular space between cells. The transport tissues forms a circle. The secretion space was not observed (Figure 4. A \& I). In stage 2 , the epidermal cells are rounded, the cuticles and stomata were not observed. There is an intercellular space between parenchymal tissue in mesophyll, the vascular bundle forms a semicircle, and there is secretory space (Figure 4. B \& H).

In stage 3 , the epidermal cells are round and panerophore in type with cuticles and stomata. In mesophyll, parenchymal tissue were found with intercellular space, vascular bundle and more number secretion space (Figure 4. C, F \& G). In stage 4, thick cuticles are found in the outer epidermis wall. There is colenchymal tissue in the hypodermis, the vascular bundle is semicircular. The secretion space is relatively more in number than the previous stages (Figure 4. D \& F). In stage 5 , the epidermis found with thick cuticles and Utaminingsih et al. cryptophore-type of stomata. There are collenchymal and parenchymal tissues with increasingly wide intercelular space. The vascular bundle was observed to be relatively larger (Figure 4. E \& H).

The plant development is influenced by external factors, xenobiotics, resources, and stressors. Xenobiotics includes air pollution, organic and inorganic poisons. Resources include light, $\mathrm{CO}_{2}$, water, nitrogen and phosphorus. Stressors include temperature, salinity, soil $\mathrm{pH}$ (Willey, 2016). Internal factors that influence the development is hormones and genes (Davies, 2010; Pierik, 1997).

Petals have cryptophore stomata (guard cells are located deeper than the epidermis) and cuticles. This is an adaptation of plants that live in dry areas or xerophytic plants. These plants also adapt through photosynthesis using the CAM (Crassulacean Acid Metabolism) mechanism, where $\mathrm{CO}_{2}$ is taken at night. This is supported by Lambers et al. (1998) which stateed that the stomata closes during the day during decarboxylation of malic acid and fixation of $\mathrm{CO}_{2}$ by Rubisco in the 


\section{JURNAL BIDDJATI}

http://journal.uinsgd.ac.id/index.php/biodjati

Calvin cycle. Stomata open during fixation of $\mathrm{CO}_{2}$ at night in the cytosol.

The type of vascular bundle in sepal is closed colateral, with the phloem is under the xylem rays but no cambium was found. This happens because in the flower the cambium that produce vascular bundle is the procambium (Fahn, 1991).

The secretion space was filled with mucus (mucilage). Mucus in the secretion space is composed of polysaccharides. The existence of a secretion chamber is one of the characteristics of the Cactaceae plant. This is supported by the discovery of the same secretion space in Cactaceae plants (Metcalfe and Chalk, 1957; Almeida, 2010).

\section{ACKNOWLEDGMENTS}

Thank you to the Research Directorate of Universitas Gadjah Mada for research funding through the 2016 Lecturer Research Capacity Enhancement Grant.

\section{REFERENCES}

Almeida, O. J. G., Sartori-Paoli, A.A. \& Souza, L.A. (2010). Flower Morpho-Anatomy in Epiphyllum phyllanthus (Cactaceae). Revista Mexicana de Biodiversidad, 81(1), 65- 80.

Davies, P. J. (2010). Plant Hormones: Biosynthesis, Signal Transduction, Action. London: Springer Science and Business Media.

Deswiniyanti, N. W., Astarini, I. A. \& Puspawati, N. M. (2012). Studi Fenologi Perbungaan Lilium longiflorum Thunb. Jurnal Metamorfosa, 1(1), 6-10.

Dickison, W. C. (2000). Integrative Plant Anatomy. United State of America: Elsevier.

Fahn, A. (1991). Anatomi Tumbuhan. Yogyakarta: Gadjah Mada University Press.
Faostat. (2018). Produksi buah tropis di Indonesia. Retrived from http://www.fao. org/faostat/en/\#data/QC.

Gunasena, H. P. M., Pushpakumara, D. K. N. G. \& Kariyawasam, M. (2006). Dragon Fruit - Hylocereus undatus (Haw) Briton and Rose: Field manual for extention workers. Sri Lanka: Sri Lanka Council for Agricultural Policy.

Hidayat, E. B. (1995). Anatomi Tumbuhan Biji. Bandung: Penerbit ITB Bandung.

Jatnika, A. (2010). Menguak Manfaat Buah Naga. Balai Besar Pelatihan Pertanian Lembang diakses pada 2 Juni 2016 http://www.bbpp-lembang.info/index.php/arsip/artikel/artikel-pertanian/506-menguak-manfaat-buah-naga.

Johansen, D. A. (1940). Plant Microtechnique. New York: McGraw-Hill Book Co. Lambers, H., Chapin, F. S. \& Pons, T. L.(1998). Plant Physiological Ecology. New York: Springer-Verlag New York Inc.

Lim, T .K. (2012). Edible Medicinal and Non-Medicinal Plants Vol 1. Springer Science and Business Media.

Metcalfe, C. R. \& Chalk L. (1957). Anatomy of Dicotyledons. Oxford: Clarendon Press.

Nugroho, L. H., Purnomo, \& Sumardi, I. (2012). Struktur dan Perkembangan Tumbuhan. Jakarta: Penebar Swadaya.

Papini, A., Mosti, A. \& Doorn, W. G. V. (2014). Classical Macroautophagy in Lobivia rauschii (Cactaceae) and Possible Plastidial Autophagy in Tillandsia albida (Bromeliaceae) Tapetum Cells. Protoplasma, 251(3), 719-725.

Pierik, R. L. M. (1997). In Vitro Culture of Higher Plant. London: Springer Science+Business Media.

Reddy, S. M., Rao, M. M., Reddy, A. S., Reddy, M. M. \& Chary, S. J. (2004). University Botany-3. New Delhi: New Age International Ltd. 


\section{JURNAL BIDDJATI}

http://journal.uinsgd.ac.id/index.php/biodjati

Ruzin, S. E. (1999). Plant Microtechnique and Microscopy. Oxford: University Press, Inc.

Soni, N. K. \& Soni, V. (2010). Fundamentals of Botany Vol. 2. New York: Tata McGraw Hill Education Private Limited.

Srivastava, L. M. (2002). Plant Growth and Development: Hormones and Environment. USA: Academic Press.

Strittmatter, L. I., Negron-Ortiz, V. \& Hickey, R. J. (2002). Subdioecy In Consolea spinosissima (Cactaceae): Breeding System and Embryological Studies. American Journal of Botany, 89(9), 1373-1387.

Tiagi, Y. D. (1954). Studies in the Floral Morphology of Opuntia dillenii Haworth. Botaniska Notiser. Hafte 4 Lund.
Umayah, E. U. \& Amrun, M. H. (2007). Uji Aktivitas Antioksidan Ekstrak Buah Naga (Hylocereus undatus (Haw.) Britt. \& Rose). Jurnal Ilmu Dasar, 8(1), 83-90.

Wang, X. X., Liu, Y. \& Liu, M. (2007). Microsporogenesis and development of male gamete in Hylocereus undatus. Journal of Fruit Science, 24(4), 541-544.

Weiss, J., Nerd, A. \& Mizrahi, Y. (1994). Flowering Behaviour and Pollination Requirements in Climbing Cacti with Fruit Crop Potential. HortScience, 29(12), 1487-1492.

Willey, N. (2016). Environmental Plant Physiology. United Kingdom: Garland Science, Taylor \& Francis Group, LLC. 